\title{
Developing web-assisted interactive media to improve mathematical creative-thinking ability
}

\author{
Andini Dwi Rachmawati ${ }^{1}$, Baiduri ${ }^{1}$, Moh. Mahfud Effendi ${ }^{1}$ \\ ${ }^{1}$ Universitas Muhammadiyah Malang \\ 凶andinidwirachmawati@gmail.com
}

\section{Article Information}

Submitted June 03, 2020

Revised September 04, 2020

Accepted October 13, 2020

Keywords

Web-assisted interactive learning media;

4D;

Creative-thinking ability.

\begin{abstract}
Millennials currently prefer web-assisted interactive media as a learning resource rather than reading books. To understand the contents of the book, students need high literacy skills. Unlike the web-assisted interactive media, the explanations are accompanied by pictures and simulations that can help students to understand the learning material. The developed webassisted interactive learning media had been adjusted to the 2013 curriculum. This research aimed to develop a valid, effective, and practical interactive web-assisted learning media. The research development model used was the 4D model which consisted of Define, Design, Development, and Dissemination stages. The instrument used in this study was a validation sheet, a questionnaire to measure the practicality, and a creativethinking test to measure the effectiveness. The results of validation showed that the developed learning media obtained an average score of $86.17 \%$ and had met the validity criteria with excellent quality. The questionnaire obtained a score of $88.39 \%$ which indicated that the developed learning media was effective. The developed web-assisted interactive learning media met the effectiveness criteria with the obtained average score of $80 \%$ based on four indicators, namely fluency, flexibility, authenticity, and detail. It can be concluded that the web-assisted interactive learning media is suitable to be used as a learning resource.
\end{abstract}

\section{INTRODUCTION}

Human resources who can compete in the world of education are needed in the era of globalization. Education is a major factor that can affect the quality of resources. It can also be used as a resource to face global competition (Shanley, 2016). The ability that must be prepared by millennials is the ability to master the technology (Irianti \& Wijaya, 2017) and how to use technology in learning by utilizing media in the learning process (Puspitarini \& Hanif, 2019).

Students need sources and learning media that can make them easier to understand concepts (Syandri, 2015). Learning media supports the learning process, especially mathematics learning (Susanto \& Suri, 2017). Digital media and various types of educational technology can support students to improve their thinking skills (Lehtola et al., 2014; Molnar, 2014). Most students think that mathematics is abstract so that understanding a concept requires high concentration and seriousness. Besides, understanding a mathematical concept also takes a relatively long time (Fan \& Xiao, 2015). Meanwhile, students' learning material understanding is the main goal of the learning process (Fadillah, 2019). Therefore, it is necessary to innovate learning media by utilizing interactive multimedia (Kusumaningtyas et al., 2018). The developed learning media for mathematics learning had been developed by using the website.

Web-assisted interactive learning media provides two-way communication without space and time barriers (Qiao \& Wang, 2017). Rohaeti et al. (2019) state that two-way learning means presenting information and visualizing abstract teaching material. Abstract material can be 
visualized through an interesting simulation (Lee, 2018). Software that supports interactive learning media used in this research was iSpring and Geogebra (Zakaria et al., 2017). iSpring is a software that can convert presentation files into the flash format and can contain animations, images, videos, and audio (Nurwijayanti et al., 2019). Geogebra is software for learning mathematics that offers geometric and algebraic features (Nisiyatussani et al., 2018; Nurdin et al., 2019).

The geometry and algebra features of the Geogebra software are also equipped to create graphical functions, show algebraic expressions, and perform numerical calculations (Farihah, 2018). An interactive learning media is not only interesting, but it also can be adapted to the applicable curriculum (Kowiyah et al., 2019). The concept of problems presented in the interactive learning media will make it easier for students to solve contextual problems (Mulyasa, 2016). Learning assisted by the web-assisted interactive media will also provide more stimulation to students (Setyaningrum, 2018). The stimulus will certainly develop students' creative-thinking ability (Maharani, 2017).

The creative-thinking ability is an independent logical opinion to find solutions to mathematical problems based on concepts and procedures (Hanipah et al., 2018; Kadir, Lucyana, 2017). Students can find solutions to mathematical problems with different points of view (Munahefi et al., 2018). The difference in viewpoints is due to differences in receiving teacher stimuli during the learning process (Maharani, 2017). However, the obstacle can be overcome by collaborating the functions of the right and left brain in a balanced manner (Piaw, 2014). So, the creative-thinking ability can facilitate students to realize their imagination and express their ideas (Ersoy \& Başer, 2014).

There are several indicators of creative-thinking, namely fluency where students can generate large amounts of ideas, flexibility where students provide different ways to solve problems with different points of view, authenticity where students can analyze the problem in their way, and detail where students provide answers and procedures in detail, clearly, and correctly (Sowden et al. , 2015;).

Several studies had been conducted by Abadi \& Fardah, 2018; Novianti et al., 2019; Setyadi, 2017; Syafitri et al., 2018 regarding the development of web-assisted interactive learning media. However, what distinguished this research from previous research was the addition of a simulation menu that utilized the Geogebra software and the material delivery and evaluation questions that able to develop students' creative-thinking ability on straight line equations. Based on the described background, the problems raised in this research were the effectiveness, validity, and practicality of the developed web-assisted interactive learning media. The purpose of this study was to develop web-assisted interactive learning media for junior high school students in a valid, practical, and effective manner.

\section{METHODS}

This research employed the Research and Development method. The product developed was a web-assisted interactive learning media. The development model used was the 4D model by Thiagarajan (1974) which consisted of 4 stages, namely Define, Design, Develop, and Disseminate. The web-assisted interactive learning media was tested at SMPN 1 Kemlagi in class VIII-A. However, the dissemination stage was only carried out in class VIII-B within the 
same school. The following is the flowchart as the reference in developing the web-assisted interactive learning media:

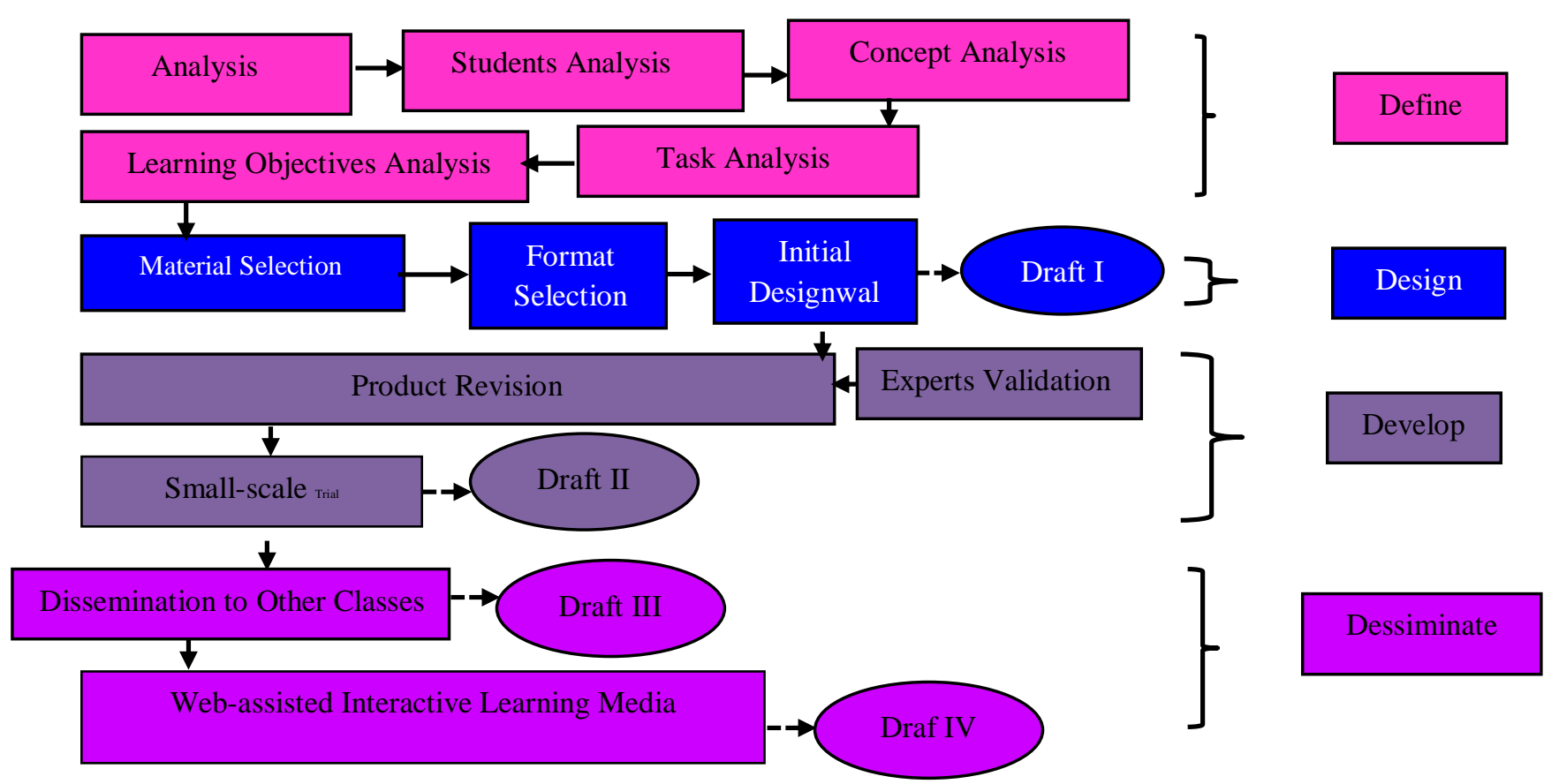

Figure 1. - The Flowchart of the Development Process

The instruments used in this research were the validation sheets for the web and media experts, questionnaires for students, and creative-thinking tests. The collected data after completing the research can be used to analyze the web-assisted interactive learning media in terms of validity, practicality, and effectiveness. The research instruments used can be seen in Table 1.

Table 1. The Details of the Instruments

\begin{tabular}{lll}
\hline Criteria & Instruments & Respondents \\
\hline Validity & Validation Sheet & Material expert, web experts, and media experts \\
Practicality & Questionnaire & Students \\
Effectiveness & Creative-Thinking Test & \\
\hline
\end{tabular}

The web-assisted interactive learning media had been developed to fulfill several components according to the 2013 curriculum. Then, the product was validated by the validators by paying attention to several aspects of the assessment. The aspects can be seen in table 2 .

Table 2. The Assessment Aspects

\begin{tabular}{clc}
\hline No. & \multicolumn{1}{c}{ Rated Aspects } & Number of Items \\
\hline 1. & Content appropriateness & 6 \\
2. & The feasibility & 9 \\
3. & The Creative-thinking & 4 \\
4. & Media completeness & 5 \\
5. & Language & 7 \\
6. & Usage & 4 \\
7. & Display & 15 \\
\hline
\end{tabular}

The questionnaire for students was used to find out the practicality of the developed learning media. The data obtained had been analyzed by calculating the predetermined components. The aspects of the questionnaire for students are displayed in Table 3. 
Table 3. The Aspects of the Questionnaire for Students

\begin{tabular}{|c|c|c|}
\hline No. & Rated Aspects & Number of Items \\
\hline 1. & Material delivery & 3 \\
\hline 2. & Creative-thinking & 4 \\
\hline 3. & Usefulness & 6 \\
\hline 4. & Interest & 2 \\
\hline
\end{tabular}

To assess the quality of the developed web-based interactive learning media, and effectiveness test had been conducted in the form of essay questions on students' creative-thinking ability.

The data analysis used in this research was qualitative tests. The validity data was based on the validator's assessment data through the validation sheet. The practicality data was obtained from the students' responses on the questionnaires while the effectiveness data was obtained from the creative-thinking test. The results of the assessment to determine the level of validity, practicality, and effectiveness had been analyzed through several steps. The first step was analyzing the level of validity by the material, media, and web experts using the validation sheet and the second step was analyzing the level of practicality. There were several stages in analyzing the level of validity and practicality of the developed media, namely changing the quantitative score obtained from the validators into quantitative data based on the following criteria;

Table 4. Score Categories of Each Instrument

\begin{tabular}{cc}
\hline Score & Category \\
\hline 1 & Poor \\
2 & Low \\
3 & High \\
4 & Excellent \\
\hline
\end{tabular}

The third step was calculating the average validation score obtained through the validation sheet by using the following formula:

$$
\text { Score }(\%)=\frac{\sum \text { the obtained score }}{\text { Maximum score }} \times 100 \%
$$

(Widoyoko, 2017)

The scores were classified qualitatively on a scale of four using the following formula:

$J I=\frac{S_{\max }-S_{\min }}{\sum K_{i}}$

$J I=\frac{100 \%-25 \%}{4}=18,75 \%$

Description:

$J I \quad=$ Interval $\quad \sum K_{i} \quad=$ The number of class interval

$S_{\max }=$ Ideal maximum score $\quad S_{\min }=$ Ideal minimum score

The interval used to determine the percentage of students' questionnaire responses was $18.75 \%$. The criteria for improvement are as follows: 
Table 5. The Criteria for Improvement

\begin{tabular}{|c|c|}
\hline Criteria & Description \\
\hline Invalid & Improvements are needed \\
\hline Less valid & \\
\hline $\begin{array}{l}\text { Valid } \\
\text { Very valid }\end{array}$ & No improvements are needed \\
\hline
\end{tabular}

The percentage of the score obtained had been converted into a five-scale qualitative value. The assessment classification guidelines are displayed in the table below.

Table 6. Guidelines for Classification of Assessment of the Validity and Practicality of the Instruments

\begin{tabular}{cll}
\hline \multicolumn{1}{c}{ Value Interval } & & Criteria \\
\hline $81,25 \%<x \leq 100 \%$ & Very Valid & Very Practical \\
$62,50 \%<x \leq 81,25 \%$ & Valid & Practical \\
$43,75 \%<x \leq 62,50 \%$ & Less Valid & Less Practical \\
$25 \%<x \leq 43,75 \%$ & Invalid & Impractical \\
\hline$x=$ The average score of the validation sheet and the students' response questionnaire
\end{tabular}

The fourth step was analyzing the level of effectiveness of the creative-thinking test by calculating the creative-thinking ability score based on the following indicators: (1) fluency; (2) flexibility; (3) authenticity; (4) detail. The four indicators contained special characteristics in solving problems which can be seen in the table below:

Table 7. The Indicators of Creative-Thinking Ability

\begin{tabular}{ll}
\hline \multicolumn{1}{c}{ Creative Thinking Indicators } & \multicolumn{1}{c}{ Reactions to Problems } \\
\hline Fluency & Able to identify problems \\
Flexibility & Show solutions to problems in more than 1 way \\
Authenticity & Provide answers in their own way \\
Details & Show solutions to problems in detail \\
\hline
\end{tabular}

Widoyoko (2017) states that the percentage score for the creative-thinking test can be obtained using the percentage score formula. The score results can be classified qualitatively on a scale of four using the following formula:

$J I=\frac{S_{\max }-S_{\min }}{\sum K_{i}}$

$J I=\frac{100 \%-0 \%}{4}=25 \%$

Description:
$J I=$ Interval
$S_{\max }=$ Ideal maximum score
$\sum K_{i} \quad=$ The number of class interval
$S_{\min }=$ Ideal minimum score 
The assessment classification guidelines are displayed in the table below:

Table 8. The Assessment Classification Guidelines of the Instruments' Effectiveness

\begin{tabular}{cl}
\hline Percentages & \multicolumn{1}{c}{ Description } \\
\hline $75 \%<\mathrm{x} \leq 100 \%$ & Very effective \\
$50 \%<\mathrm{x} \leq \leq 75 \%$ & Effective \\
$25 \%<\mathrm{x} \leq 50 \%$ & Less effective \\
$0 \%<\mathrm{x} \leq 25 \%$ & Ineffective \\
\hline
\end{tabular}

$\mathrm{x}=$ The average score of the results of the creative thinking test and the questionnaire for students

\section{RESULTS AND DISCUSSION}

The web-assisted interactive learning media had been developed with the 4D model proposed by Thiagarajan (1974) which includes four stages, namely Define, Design, Develop, and Disseminate. Based on the development, the following results were obtained:

\section{The Define Stage}

At the Define stage, several stages were carried out, namely the needs, characteristics of students, and the curriculum analysis. The needs analysis was carried out to analyze existing problems and needs. As a result, teachers did not use interactive learning media in teaching and learning activities in the classroom. The learning media used was simple so that the students' creative-thinking ability unable to be developed. The next analysis was the analysis of students' characteristics. It was found that the students only listened to the teacher's explanation during learning activities. Not all students were actively involved and many students were passive during learning.

The last analysis was curriculum analysis. SMP 1 Kelagi Mojokerto has applied the 2013 curriculum. However, the teaching and learning processes were teacher-centered. This caused a mismatch with the principles of the 2013 curriculum which prioritizes students and studentcentered. Based on the analysis, it can be concluded that students must be at the center of learning and possess a high creative-thinking ability. For this reason, the developed webassisted interactive learning media served as a solution to overcome the mentioned problems.

\section{The Design Stage}

The Design stage consisted of several steps. The first step was selecting media that was relevant to the concept, namely using Microsoft PowerPoint. Furthermore, the simulation menu was created with the help of the Geogebra software. The developed web-assisted interactive learning media displays a home menu on the start page and 6 other menu pages, namely concept maps, content standards, materials, quizzes, evaluations, and profiles. The following are the displays of the home page, concept map, standard content, material, quiz simulation, evaluation, and profile. 


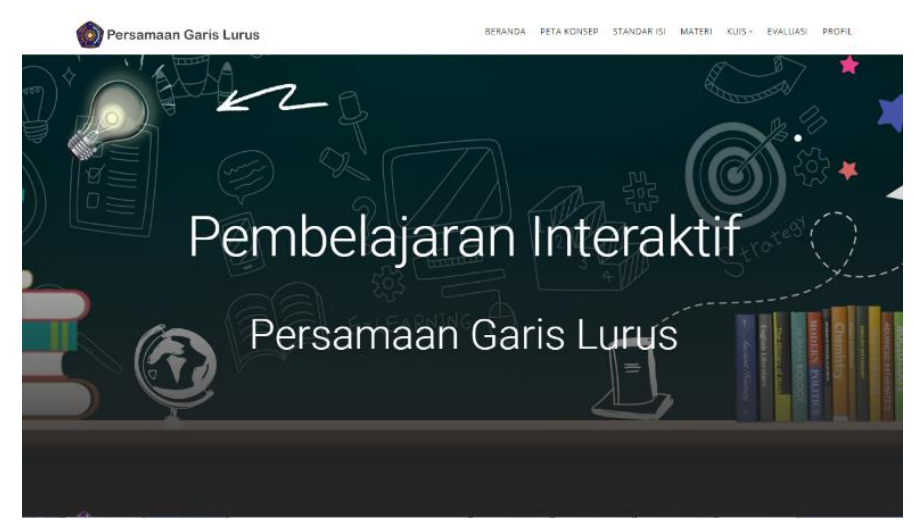

Figure 2. The Home Menu

The second menu is a concept map that describes and determines the standard content of the straight line equation material. The following is the display of the concept map menu and content standards.

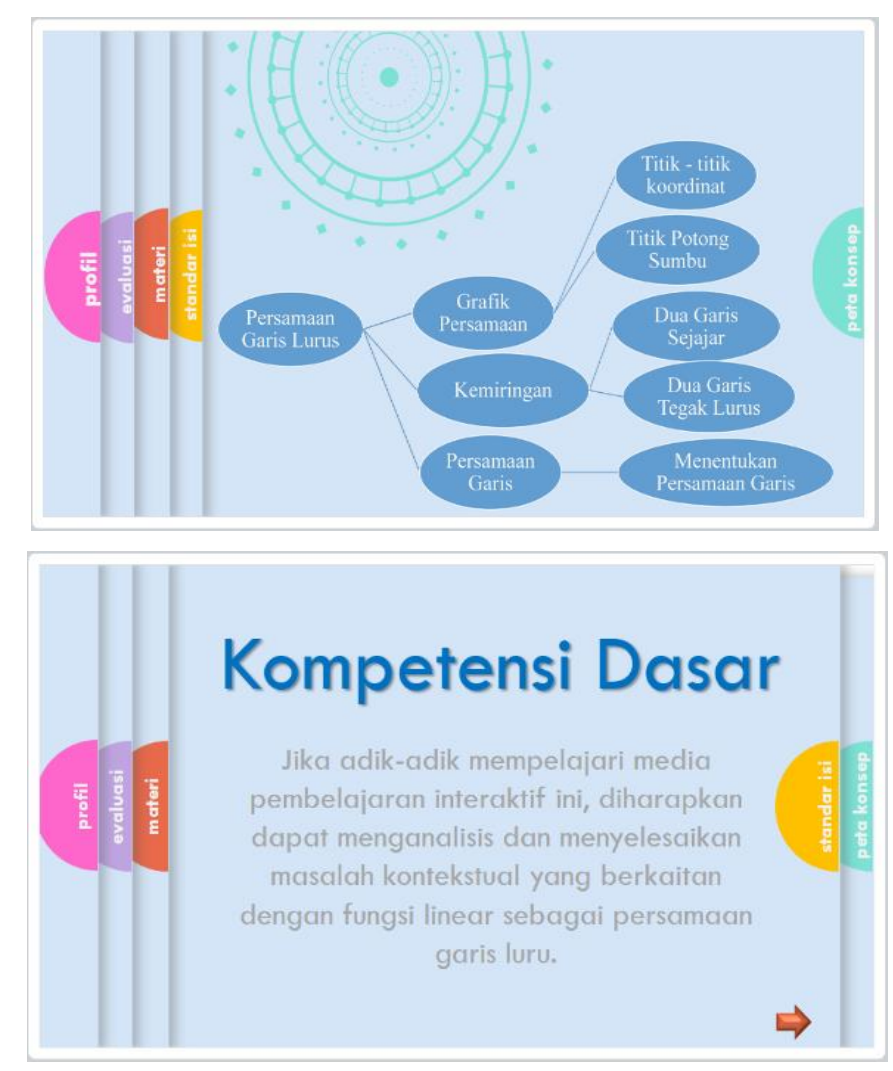

Figure 3. The Concept Map Menu and Content Standards

The third menu is learning material. The learning material menu contains illustrations. Then, for students to better understand the concept of a subject, two additional menus are presented, namely quizzes and simulations. When the quiz menu is clicked, several questions will appear. However, to answer these questions, students must go through a simulation first. That is why the quiz and simulation menus were two interrelated menus. Students who answer questions on the quiz menu can understand the concepts. The following is an example of the material menu when the simulation button is clicked. 
Rachmawati, A. D., Baiduri, B., \& Effendi, M. M.
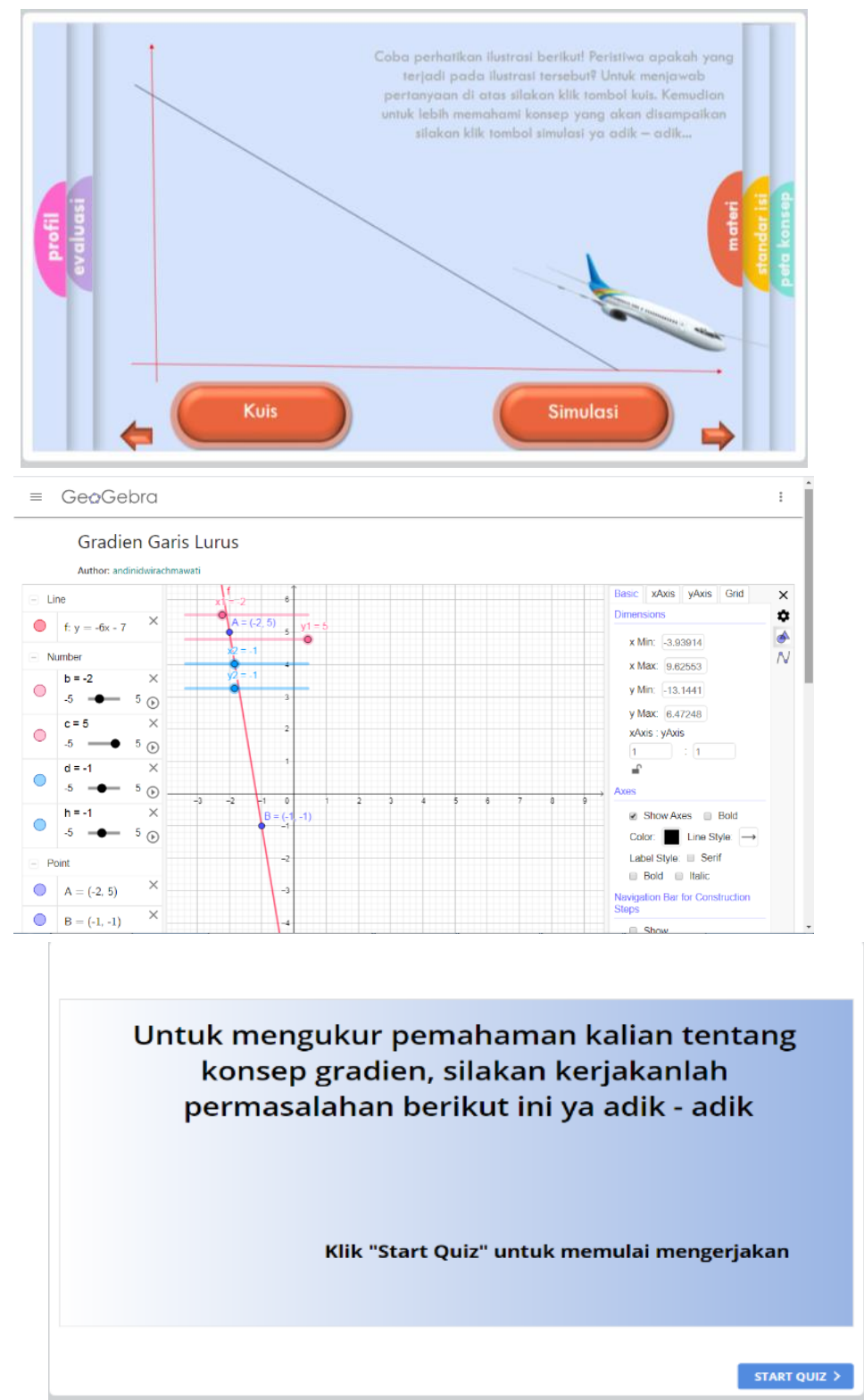

Figure 4. The Material Menu, Quizzes, and Simulations

The fourth is the student evaluation menu which consists of only one item. It aims to assess the level of creative thinking ability. On the evaluation menu, students can read the questions where they are required to click the answer sheet button to write their answers.

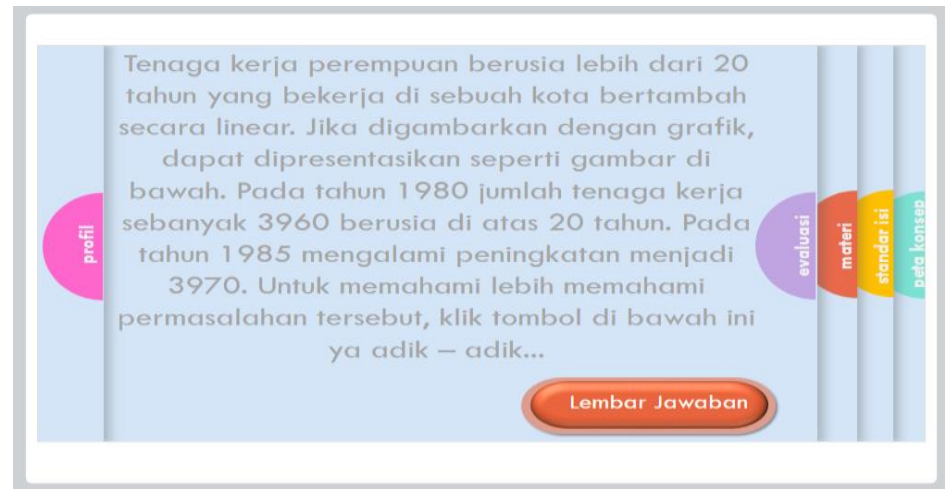


Rachmawati, A. D., Baiduri, B., \& Effendi, M. M.

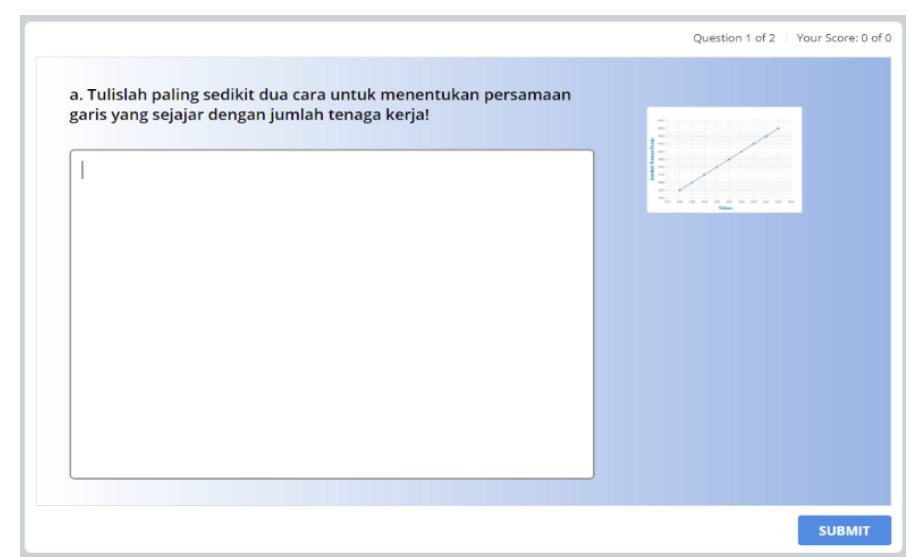

Figure 5. The Evaluation Menu

The fifth menu is the profile menu. This menu contains some information related to education and the author's philosophy. At the end of the profile menu display, there is a questionnaire button. The questionnaire was deliberately made online to make students' easier to assess the web-assisted interactive learning media used during learning.

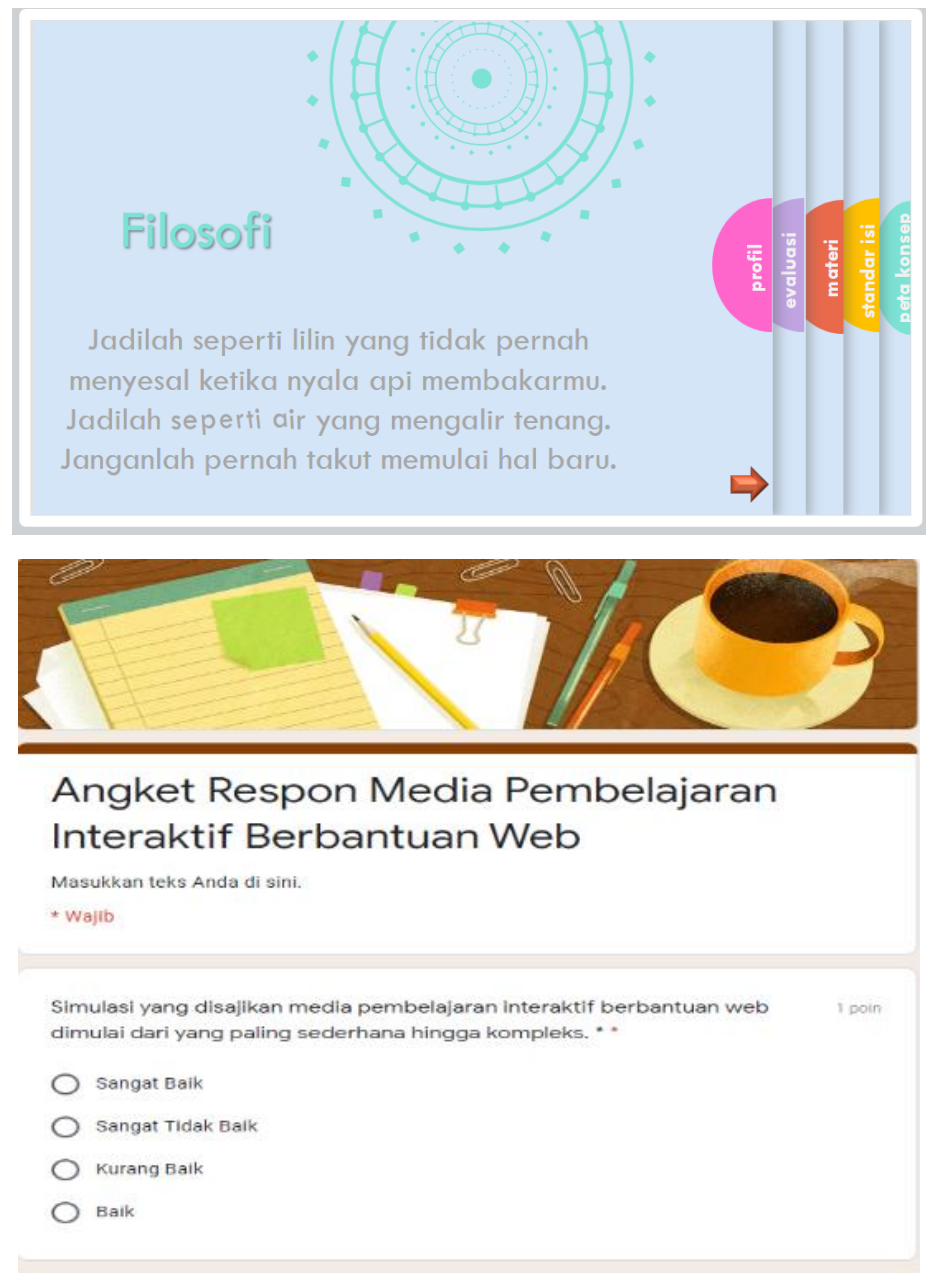

Figure 6. Profile and Questionnaire Menu 


\section{The Develop Stage}

The Develop stage was the most important since in this stage, the validity, practicality, and effectiveness could be determined through trials. At this stage, the initial draft was submitted to be validated by the experts. The validation was carried out by several experts, namely the web experts, media experts, and material experts. The selected experts possessed expertise in the use of media, websites, delivery of material, and had a master's degree. The material experts validation covered three aspects, namely the content feasibility aspect with a score of $85.7 \%$, the implementation aspect with a score of $84.4 \%$, and the creative thinking aspect with a score of $87.5 \%$. This indicated that the developed learning media had met core competence and basic competence of the material presented.

The web experts validation consisted of one aspect, namely the display aspect with a score of $85 \%$. Users understood the writings used in the web-assisted interactive learning media. However, the color selection should be improved because the website's coloring was not quite right. The media experts validation covered three aspects, namely the completeness aspect with a score of $85.9 \%$, the language aspect with a score of $85.7 \%$, and the usage aspect with a score of $93.8 \%$. This indicated that the coloring helped the students to deepen their conceptual understanding. The placement of titles and subtitles also did not disturb the users' understanding. However, improvements were made in terms of backgrounds, fonts, and terms. The developed learning media had fulfilled the validity criteria based on the validation results by the experts. Based on the data analysis, the developed web-assisted interactive learning media was considered very valid and feasible as the result of expert validation.

The questionnaire covered several aspects. The material delivery aspect obtained a score of $89.32 \%$ which indicated that the simulations in the web-assisted interactive learning media had been started from the simplest to the complex. Each simulation is related to one another. Besides, the simulations matched the material discussed. Furthermore, the creative-thinking aspect obtained a score of $88.48 \%$ which indicated that the web-assisted interactive learning media can help students to identify problems, develop varied ideas independently, and solve problems in detail. The usefulness and interest aspects obtained the scores of $87.37 \%$ and $88.28 \%$ respectively. Students could find concepts and conclude based on the material obtained independently.

Besides, the students were interested to use the web-based interactive learning media repeatedly. Based on the practicality category in table 4, the developed learning media was included in the very practical category. Since the web-assisted interactive learning media had been categorized as very practical, it did not need improvement. Thus, the web-assisted interactive learning media was very practical and feasible to use.

After analyzing the level of practicality, the next stage was analyzing the effectiveness. The level of effectiveness was obtained from the creative-thinking test. The results of the test can be illustrated as follows: 


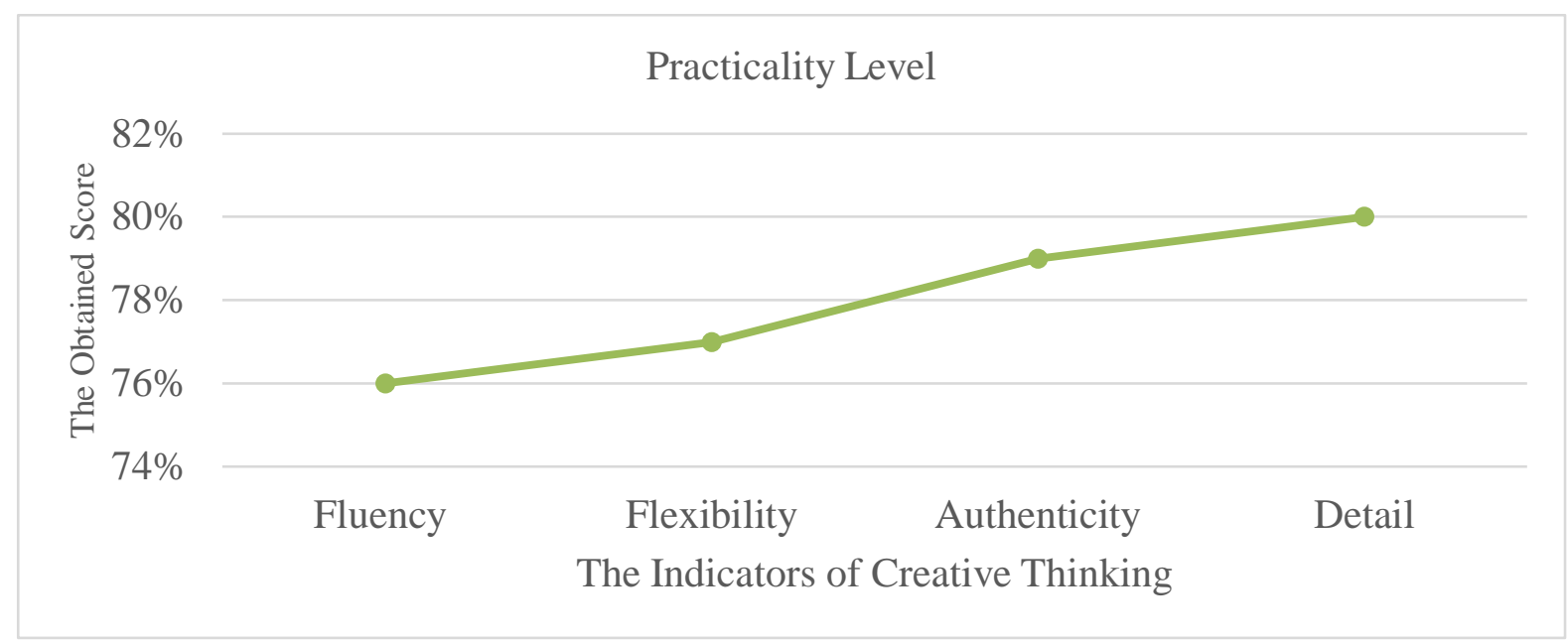

Figure 7. Flexibility

On the indicator of fluency, the students were able to explain how to solve problems even though they experienced difficulties. Also, the fluency indicator can determine the ability to solve problems in more than one way. The indicator of flexibility can measure the ability of students in several ways. Students were able to provide variations in solving a problem with different approaches. They were also able to carry out the calculation correctly.

In the authenticity indicator, the students could determine the methods in finding solutions to given problems. When students have a good creative-thinking ability, they can arrange the steps in finding solutions. The purpose of preparing the steps in detail is to avoid misunderstanding the problems. Based on the effectiveness category, the detailed indicator of the creative-thinking ability was included in the very effective category.

\section{The Disseminate Stage}

The dissemination of the web-assisted interactive learning media was limited to the same school, but different class. The dissemination of the web-assisted interactive learning media had been carried out in class VIII-B with the same number of students, namely 30 students. The class used during the dissemination stage received the same treatment as the trial class. The students were allowed to take creative-thinking tests. After the learning ended, students were allowed to fill out a response questionnaire. The responses of the questionnaire and the result of the test were used to see the level of practicality and effectiveness.

The questionnaire obtained an average score of $91.61 \%$ with a very practical category. From the recapitulation of students' responses through the questionnaire, the dissemination developed web-assisted interactive learning media had fulfilled the practicality aspects. The material delivery indicator obtained a score of $91.15 \%$ with a very practical category. The developed learning media helped the students to understand the concept of the material presented. The simulations led them to study from the simple to complex materials. Furthermore, the simulations were interrelated with one another. The creative thinking aspect obtained a score of $91.41 \%$.

This web-assisted interactive learning media had been developed to develop students' creative-thinking skills. The developed learning media can help students to develop their ability to generate numerous, varied, and new ideas so that they can solve problems in detail. The useful aspect obtained a score of $92.06 \%$ because the developed learning media made it easy to understand concepts, both independently and in groups. 
After the learning had been completed, the students could provide their conclusions based on the studied material. Various illustrations and simulations were able to develop students' abilities in solving problems, especially during evaluation. The improvements made the students more active and creative in learning. $06 \%$ is due to web-assisted interactive learning media that makes it easy to understand concepts both independently and in groups. After learning is complete, students can also provide their own conclusions according to the material being studied.

Various illustrations and simulations made can develop students' abilities in solving problems, especially during evaluation. The improvements made will make students more active and creative in learning. The majority of students' stated that the developed learning media was interesting and very practical with an obtained score of $91.80 \%$ because it can be used repeatedly and use easy to understand language.

After analyzing the level of practicality, the next stage was analysing the effectiveness. The level of effectiveness had been obtained from the creative-thinking test. The effectiveness category obtained from the creative-thinking test showed that the fluency indicator was categorized as very effective with a score of $78 \%$. In the fluency indicator, students could provide more than one idea. The fluency indicator showed the true level of students' ability in solving problems. However, some students had difficulty in generating lots of ideas.

The flexibility indicator obtained a score of $81 \%$ with an excellent category. The flexibility indicator can measure the students' ability in several ways. The students were able to provide variations in solving problems with different approaches. They were able to carry out the calculation process correctly.

The third indicator was the authenticity indicator. The authenticity indicator was included in the quite good category with a score of $84 \%$. The students could determine the methods in finding solutions to the given problems. The last indicator was the detail indicator. When students have a good creative-thinking ability, they can arrange the steps in finding solutions. The purpose of preparing the steps in detail is to avoid misunderstanding the problems. The detail indicator was included in the excellent category with a score of $82 \%$.

This research was development research that aimed at producing web-assisted interactive learning media. The developed web-based interactive learning media for junior high school students was adapted from the criteria proposed by Nieveen (1999) which consisted of the validity, practical, and effective assessments. Sugiyono (2017) explains that the developed product must be tested and the researcher must adjust it to the validator's suggestions to produce a better product. This is in line with the opinion of Bernard \& Senjayawati (2019) that learning media can change the mindset of students and make teaching and learning activities more fun.

This research was also supported by the research of Selvy et al. (2020) that the creativethinking ability can be developed through web-assisted interactive learning media combined with some software. The software used was the Geogebra software. It can attract the students' attention through simulations carried out independently (Seprianto et al., 2019). The development of web-assisted interactive learning media combined with iSpring and PowerPoint developed by Maryana et al., (2019) indicated that the learning media can be used as a facilitator in developing students' creative-thinking ability.

This research was characterized by the use of several computer programs. The programs used were iSpring, PowerPoint, and Geogebra. The Geogebra software contributed in the form 
of a simulation menu. Through the simulation menu, students could gain new knowledge and creativity in learning. The most important part of web-assisted interactive learning media was the evaluation menu where the students were faced with a problem. The focused topic was the straight-line equations. The evaluation questions were arranged based on the specification of creative-thinking.

\section{CONCLUSIONS}

Based on the results of the validation, the developed learning media had fulfilled the validity criteria with excellent quality. The students' responses obtained through the questionnaire indicated that the developed learning media was effective. The creative-thinking test had been constructed based on the fluency, flexibility, authenticity, and detail indicators. Therefore, the developed web-assisted interactive learning media was suitable to be used as a learning resource.

Several suggestions are proposed based on the results of development. Firstly, the webassisted interactive learning media can be used in other materials for the seventh, eighth, or ninth-grade students. Secondly, this web-assisted interactive learning media can be further developed with a more perfect development process. Thirdly, a comparative study should be done against the classes that do not apply interactive learning media. Lastly, the students are expected to practice working more complex problems frequently and not be fixated on the sample questions presented by the teacher.

\section{AUTHOR CONTRIBUTIONS STATEMENT}

ADR participated in writing the original draft as well as conceptualization, while B and MM participated in methods, data curation, validation. for editing done with all authors.

\section{REFERENCES}

Abadi, \& Fardah, D. K. (2018). Students' activities for understanding function shifting by using GeoGebra. Journal of Physics: Conference Series, 1108(1).

Bernard, M., \& Senjayawati, E. (2019). Developing the students' ability in understanding mathematics and self-confidence with VBA for Excel. JRAMathEdu (Journal of Research and Advances in Mathematics Education), 1(1), 45-56.

Ersoy, E., \& Başer, N. (2014). The effects of problem-based learning method in higher education on creative thinking. Procedia - Social and Behavioral Sciences, 116, 34943498.

Fadillah, A. (2019). Analisis kemampuan penalaran deduktif matematis siswa. JTAM| Jurnal Teori Dan Aplikasi Matematika, 3(1), 15.

Fan, K., \& Xiao, P. (2015). The effects of learning styles and meaningful learning on the learning achievement of gamification health education curriculum. Eurasia Journal of Mathematics, Science and Technology Education, 11(59), 1211-1229. 
Farihah, U. (2018). Students' thinking preferences in solving mathematics problems based on learning styles: A comparison of paper-pencil and geogebra. Journal of Physics: Conference Series, 1008(1).

Hanipah, N., Yuliani, A., \& Maya, R. (2018). Analisis kemampuan berpikir kreatif matematis siswa MTS pada materi lingkaran. AKSIOMA: Jurnal Program Studi Pendidikan Matematika, 7(1).

Irianti, N. P., \& Wijaya, E. M. S. (2017). Pengembangan media pembelajaran e-learning berbasis moodle pada pokok bahasan lingkaran kelas VIII SMP. Jurnal Ilmiah Pendidikan Matematika, 5(2), 122-130.

Kadir, Lucyana, G. S. (2017). The Implementation of open-inquiry approach to improve students ' learning activities, responses, and mathematical creative thinking skills. Journal on Mathematics Education, 8(1), 103-114.

Kowiyah, K., Mulyawati, I., \& Umam, K. (2019). Conceptual understanding and mathematical representation analysis of realistic mathematics education based on personality types. $\mathrm{Al}$ Jabar : Jurnal Pendidikan Matematika, 10(2), 201-210.

Kusumaningtyas, N., Trapsilasiwi, D., \& Fatahillah, A. (2018). Pengembangan media pembelajaran interaktif online berbantuan desmos pada kelaskita materi program linier kelas XI SMA. Kadikma, 9(3), 118-128.

Lee, Y. (2018). Emotional design in multimedia learning : Effects of multidimensional concept maps and animation on affect and learning. Eurasia Journal of Mathematics Science and Technology Education, 14(12).

Lehtola, W. I., Gemignani, S. M., Sutherland, J. T., \& Jeon, M. (2014). "Not all visual media are helpful ": An optimal instructional medium for effective online learning. In Human Factors and Ergonomics Society 58th Annual Meeting (pp. 1351-1355).

Maharani, A. (2017). Analisis Pengembangan soal tes evaluasi matematika berbasis kemampuan berpikir kreatif untuk siswa smk pada materi geometri. AKSIOMA: Jurnal Program Studi Pendidikan Matematika, 6(3).

Maryana, Suaedi, \& Nurdin. (2019). Pengembangan media pembelajaran matematika menggunakan powerpoint dan ispring quizmaker pada materi teorema pythagoras. Proximal, 2(3), 53-61.

Molnar, V. (2014). Space and culture reframing public space through digital mobilization: Flash mobs and contemporary. Space and Culture, 17(1), 43-58.

Mulyasa, E. (2016). Menjadi guru profesional (VIII). Bandung: PT Remaja Rosdakarya.

Munahefi, D. N., Waluya, S. B., \& Rochmad. (2018). Analysis of creative mathematic thinking ability in problem based learning model based on self- regulation learning. Journal of Physics: Conference Series, 983(1), 1-5.

Nieveen, N. (1999). Prototyping to reach product quality. Design Approaches and Tools in Education and Training, 125-135. 
Nisiyatussani, Ayuningtyas, V., Fathurrohman, M., \& Anriani, N. (2018). GeoGebra applets design and development for junior high school students to learn quadrilateral mathematics concepts. Journal on Mathematics Education, 9(1), 27-40.

Novianti, V., Utomo, D. P., \& Dintari, M. (2019). Development of web - based interactive learning media on lines and angles material in 7th grade of Junior High School. Mathematics Education Journals, 3(1), 62-71.

Nurdin, E., Ma'aruf, A., Amir, Z., Risnawati, R., Noviarni, N., \& Azmi, M. P. (2019). Pemanfaatan video pembelajaran berbasis Geogebra untuk meningkatkan kemampuan pemahaman konsep matematis siswa SMK. Jurnal Riset Pendidikan Matematika, 6(1), 87-98.

Nurwijayanti, A., Budiyono, \& Fitriana, L. (2019). Combining google sketchup and ispring suite 8: A breakthrough to develop geometry learning media. Journal on Mathematics Education, 10(1), 103-115.

Piaw, C. Y. (2014). Effects of gender and thinking style on student's creative thinking Ability. Procedia - Social and Behavioral Sciences, 116, 5135-5139.

Puspitarini, Y. D., \& Hanif, M. (2019). Using learning media to increase learning motivation in elementary school. Anatolian Journal of Education, 4(2), 53-60.

Qiao, F., \& Wang, H. (2017). Mobile interactive translation teaching model based on "internet +." Eurasia Journal of Mathematics, Science and Technology Education, 13(10), 67056714.

Rohaeti, E. E., Bernard, M., \& Primandhika, R. B. (2019). Developing interactive learning media for school level mathematics through open-ended approach aided by visual basic application for excel. Journal on Mathematics Education, 10(1), 59-68.

Selvy, Y., Ikhsan, M., Johar, R., \& Saminan. (2020). Improving students' mathematical creative thinking and motivation through GeoGebra assisted problem based learning. Journal of Physics: Conference Series, 1460(1).

Seprianto, M. I., Jumadi, \& Suhendar, U. (2019). Pembelajaran matematika materi persamaan garis lurus dengan model guided discovery learning berbantuan Geogebra. Matemtika Ilmiah STKIP Muhammadiyah Kuningan, 5(2), 78-90.

Setyadi, D. (2017). Pengembangan media pembelajaran matematika berbasis web pada materi barisan dan deret. Kreano, 8(1), 1-7.

Setyaningrum, W. (2018). Blended learning: Does it help students in understanding mathematical concepts?. Jurnal Riset Pendidikan Matematika, 5(2), 244-253.

Shanley, L. (2016). Evaluating longitudinal mathematics achievement growth: Modeling and measurement considerations for assessing academic progress. Educational Researcher, 45(6), 347-357.

Sowden, P. T., Pringle, A., \& Gabora, L. (2015). The shifting sands of creative thinking: Connections to dual-process theory. Thinking and Reasoning, 21(1), 40-60. 
Sugiyono. (2017). Metode penelitian pendidikan pendekatan kuantitatif, kualitatif, dan $R \& D$. Bandung: Alfabeta.

Susanto, F., \& Suri, I. R. A. (2017). Pengembangan perangkat pembelajaran model kooperatif tipe NHT dengan strategi pemecahan masalah (problem solving) sistematis bagi peserta didik SMP di Kabupaten Pringsewu. Aksioma, 6(3), 301-307.

Syafitri, Q., Mujib, M., Netriwati, N., Anwar, C., \& Wawan, W. (2018). The mathematics learning media uses Geogebra on the basic material of linear equations. Al-Jabar : Jurnal Pendidikan Matematika, 9(1), 9.

Syandri, G. (2015). A case study on the used of visual media in English instructional process at State Islamic Secondary School 1 Malang. Journal of Research \& Method in Education, 5(4), 46-56.

Thiagarajan, S. (1974). Instructional development for training teachers of exceptional children: A sourcebook. Indiana: Indiana University Bloomington.

Widoyoko, S. E. P. (2017). Teknik penyusunan instrumen penelitian. Yogyakarta: Pustaka Pelajar.

Zakaria, Hadiarti, D., \& Fadhilah, R. (2017). Pengembangan instrumen evaluasi berbasis CBT dengan software ispring quizmaker pada materi kesetimbangan kimia. Pendidikan Matematika Dan Sains, 1866(2), 178-183. 